\title{
Syphilis: diagnosis, treatment and control Sífilis: diagnóstico, tratamento e controle
}

\author{
João Carlos Regazzi Avelleira $\quad$ Giuliana Bottino ${ }^{2}$
}

\begin{abstract}
Syphilis is an infectious disease transmitted through sex or vertically during pregnancy. It is characterized by periods of activity and latency, disseminated systemic involvement, and progression to acute complications in patients that remain untreated or have been inadequately treated. Syphilis is known since the 15 th century and studied by all medical specialties, particularly by Dermatology. The etiologic agent Treponema pallidum has never been cultured and was described over 100 years ago. The disease has been effectively treated with penicillin since 1943, but it remains an important health problem in developed and developing countries. Given its transmission characteristics, the condition has accompanied the behavioral changes in society in recent years and has become even more important due to the possibility of increasing the risk of transmitting acquired immunodeficiency syndrome. New laboratory tests and methods of control aimed at appropriate treatment of patients and their partners, use of condoms, and dissemination of information to the population comprise some measures to control syphilis adopted by health program organizers.

Keywords: Sexually transmitted diseases; Syphilis, congenital; Treponemal infections; Treponema pallidum

Resumo: A sifilis é doença infecto-contagiosa, transmitida pela via sexual e verticalmente durante a gestação. Caracteriza-se por períodos de atividade e latência; pelo acometimento sistêmico disseminado e pela evolução para complicações graves em parte dos pacientes que não trataram ou que foram tratados inadequadamente. É conbecida desde o século $\mathrm{XV}$, e seu estudo ocupou todas as especialidades médicas e, de modo especial, a dermatologia. Seu agente etiológico, o Treponema pallidum, nunca foi cultivado e, apesar de descrito bá mais de 100 anos e sendo tratado desde 1943 pela penicilina, sua droga mais eficaz, continua como um problema de saúde importante em países desenvolvidos ou subdesenvolvidos. Dadas as características da forma de transmissão, a doença acompanbou as mudanças comportamentais da sociedade e nos últimos anos tornou-se mais importante ainda devido à possibilidade de aumentar o risco de transmissão da síndrome de imunodeficiência adquirida. Novos testes laboratoriais e medidas de controle principalmente voltadas para o tratamento adequado do paciente e parceiro, uso de preservativo, informação à população fazem parte das medidas adotadas para controle da sífilis pelos responsáveis por programas de saúde.

Palavras-chave: Doenças sexualmente transmissiveis; Infecções por treponema; Sífilis congênita; Treponema pallidum
\end{abstract}

\footnotetext{
Conflict of interest: None

Ph.D. in Medicine, Assistant Professor at the Instituto de Dermatologia Prof. Rubem David Azulay. Santa Casa de Misericórdia do Rio de Janeiro - Rio de Janeiro (RJ), Brazil.

M.D., post-Graduate student at the Instituto de Dermatologia Prof. Rubem David Azulay. Santa Casa de Misericórdia do Rio de Janeiro - Rio de Janeiro (RJ), Brazil.

CC2006 by Anais Brasileiros de Dermatologia
} 


\section{INTRODUCTION}

Syphilis is a chronic infectious disease that has challenged humanity for centuries. It affects practically all organs and systems, and in spite of having an efficacious and low-cost treatment, it continues as a public health problem until today.

Syphilis became well known in Europe at the end of the 15th century, and its rapid dissemination throughout the continent transformed it into one of the world's main plagues. Since it involves skin and mucous membranes in such a florid way, it has a strong link with dermatology (Figure 1).

Two theories have been drawn up in order to explain its origin. According to the first hypothesis, called the Colombian theory, syphilis was endemic in the New World and was introduced in Europe by Spanish sailors who had participated in the discovery of America. Others believed that syphilis developed out of mutations and adaptations undergone by endemic species of treponemas from the African continent. ${ }^{1}$

Synonyms of the disease reflect the belligerent sociopolitical situation of Europe in which the disease was always attributed a characteristic that identified it with another people or nation. The Spanish Disease, the Italian Disease, the French Disease, were all used until the name syphilis, derived from a poem by Hieronymus Fracastorius, became its main denomination.

Growth of endemic syphilis during the 19th century was alarming. On the other hand, medicine was progressing and the synthesis of the first drugs came about. The greatest impact was probably caused by the introduction of penicillin that, because of

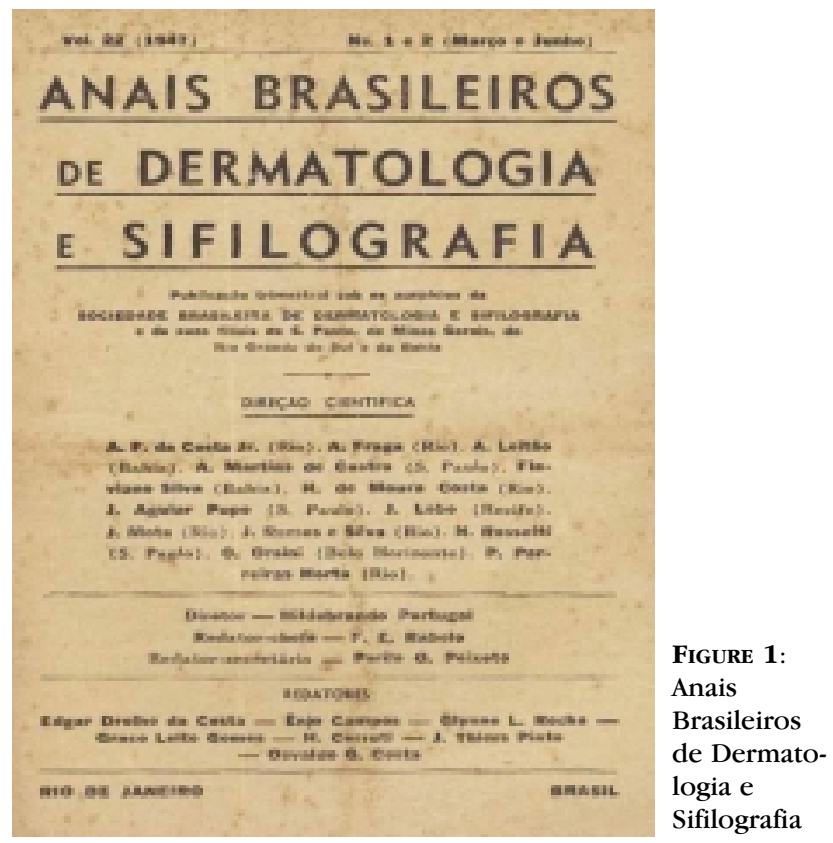

its efficacy, led many to think that the illness had been controlled, and decreased interest in studying and controlling syphilis.

In 1960, societal changes regarding sexual behavior and the advent of birth control pills caused the number of cases to rise again. At the end of the 1970 s, with the appearance of the acquired immunodeficiency syndrome (AIDS), there was a new focus on sexually transmitted diseases. The role of syphilis as a facilitating factor in transmitting the HIV virus brought about a new interest in syphilis and the need for strategies for its control.

\section{EPIDEMIOLOGY}

The World Health Organization (WHO) esteem that there are 340 million new cases of curable sexually transmitted diseases (STD) - syphilis, gonorrhea, chlamydial infection, trichomoniasis - and 12 million cases in Brazil.

Prevalence data in the Tropics show that, according to the region, syphilis is the second or third cause of genital ulcers (others are chancroid and genital herpes). ${ }^{2}$ There was a recrudescence of syphilis in Ireland, ${ }^{3}$ Germany ${ }^{4}$ and American cities such as San Francisco and Los Angeles, in risk behavior groups, such as homosexual men (MSM) and sex professionals. ${ }^{5-8}$ There was an $11.2 \%$ increase in primary syphilis in the United States, raising from 7177 cases, in 2003 , to 7980 , in $2004 .{ }^{9}$

Regarding congenital syphilis, data collected in pre-natal programs and maternities showed an elevated seroprevalence, especially in African countries. ${ }^{10-12}$

In Brazil, there were an estimated 843300 cases of syphilis in 2003. Since it is not a compulsory notification disease, epidemiological studies are carried out in facilities that treat STD or selected groups of patients, such as pregnant women, soldiers, prisoners, etc. ${ }^{13-15}$ Congenital syphilis cases recorded between 1998 and 2004 totaled 24448 . $^{13,16,17}$

\section{THE ETIOLOGICAL AGENT}

Syphilis is caused by a bacterium named Treponema pallidum, genus Treponema, of the Treponemataceae family that also includes two other genera: Leptospira and Borrelia. The genus has four pathogenic species and at least six non-pathogenic species. The pathogenic species are Treponema pallidum subsp pallidum, which causes syphilis, Treponema carateum, responsible for pinta, and Treponema pertenue, the agent for yaws or framboesia. Endemic syphilis or bejel is attributed to the $T$. pallidum subsp endemicum variant.

The T. pallidum has the shape of a spiral (10 to 
20 coils), about $5-20 \mu \mathrm{m}$ long and only 0.1 to $0.2 \mu \mathrm{m}$ wide. There is no cellular membrane and it is protected by an external envelope with three layers rich in molecules of $\mathrm{N}$-acetyl muramic acid and $\mathrm{N}$-acetyl glucosamine acid. It bears flagella that start at the distal extremity of the bacteria and are situated in the external layer along the longitudinal axis. Movement occurs by rotation of the body around these filaments (Figure 2). . $^{18-21}$

T. pallidum is not culturable and it is an exclusively human pathogen, in spite of the fact that it causes experimental infections when inoculated in monkeys and rats. Since it is destroyed by heat and lack of humidity, it does not survive for very long out of its environment ( 26 hours). It divides transversally every 30 hours. ${ }^{18-21}$

The small difference in density between the body and the wall of the T. pallidum hinders its visualization with direct light under the microscope. It does not stain well, hence the name - pallid, from the Latin pallidum.

The T. pallidum subsp pallidum genome was recently sequenced. It is a circular chromosome with $1138006 \mathrm{bp}$ (base pairs) and 041 ORFs (open reading frame). Its biosynthesis capacity is limited, and it therefore prefers low oxygen locations and has few proteic components in its external wall. ${ }^{18}$

\section{ETIOPATHOGENESIS}

Penetration of the treponema is carried out by small abrasions resulting from sexual intercourse. Soon after that, the treponema reaches the regional lymphatic system and then, by hematogenous dissemination, other parts of the body. The local defense response causes erosion and exulceration at the point

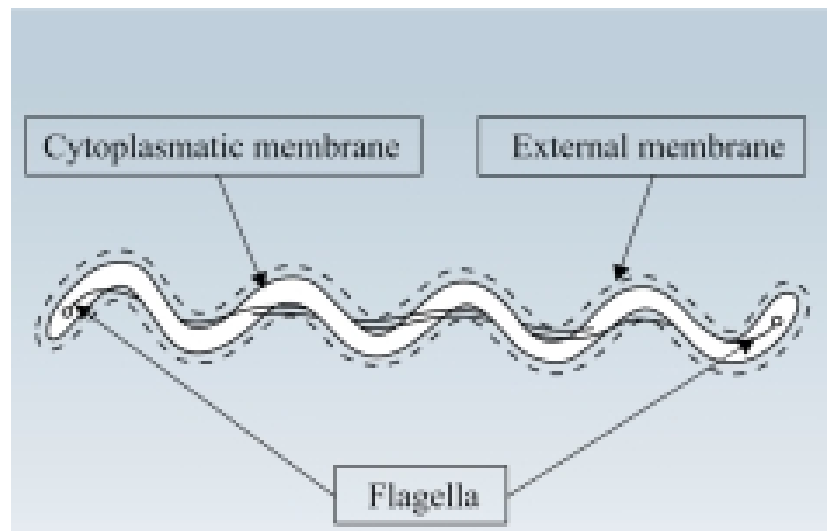

FIGURE 2: Schematic drawing of Treponema pallidum. In: Trabulsi. Microbiologia of inoculation, while systemic dissemination leads to the production of circulating immune complexes that may be deposited in any organ. Nevertheless, humoral immunity is not capable of offering protection. Cellular immunity kicks in later, allowing the T. pallidum to multiply and survive for long periods.

\section{TRANSMISSION}

Syphilis is a disease transmitted sexually (acquired syphilis) and vertically (congenital syphilis) via placenta from the mother to the fetus. Contact with contagious lesions (hard chancre and secondary lesions) by the genital organs is responsible for $95 \%$ of syphilis cases.

Other less common forms of transmission that are not as significant epidemiologically are through indirect routes (contaminated objects, tattoos) and blood transfusions. ${ }^{22}$ The risk of contagion varies from $10 \%$ to $60 \%$ according to most authors. ${ }^{5,13,22}$

\section{CLINICAL ASPECTS}

The natural history of the disease shows an evolution that alternates periods of activity with distinct clinical, immune, and histopathological characteristics (primary, secondary, and tertiary syphilis) and periods of latency (latent syphilis). Syphilis can be further divided into recent syphilis, in cases when the diagnosis is made within one year after infection, and late syphilis, when this diagnosis occurs after one year.

\section{PRIMARY SYPHILIS}

The distinguishing lesion is the hard chancre at the inoculation site about three weeks after the infection. Initially it appears as a pink papule that progresses to a more intense red color and exulceration. Usually there is a single painless chancre with hardened borders and a depressed and smooth, clean center covered by serous material and practically no perilesional inflammatory manifestations. After one or two weeks, a bilateral multiple regional lymph node reaction appears that is non-suppurative, with hard painless nodules (Figure 3).

In $90 \%$ to $95 \%$ of cases, this is located in the genital region. In men it is more common in the balanopreputial fold, prepuce, urethral meatus, or rarely, intra-urethrally. In women, it is more frequently located in labia minora, vaginal wall, and uterine cervix. It is asymptomatic and many times not reported by patients. The most common extragenital locations are the anal region, mouth, tongue, mammary region, and fingers. The chancre spontaneously recedes in four to five weeks without leaving a scar. ${ }^{19,20,23}$

Absence of a primary lesion usually occurs because of transfusions with infected blood ("decapi- 


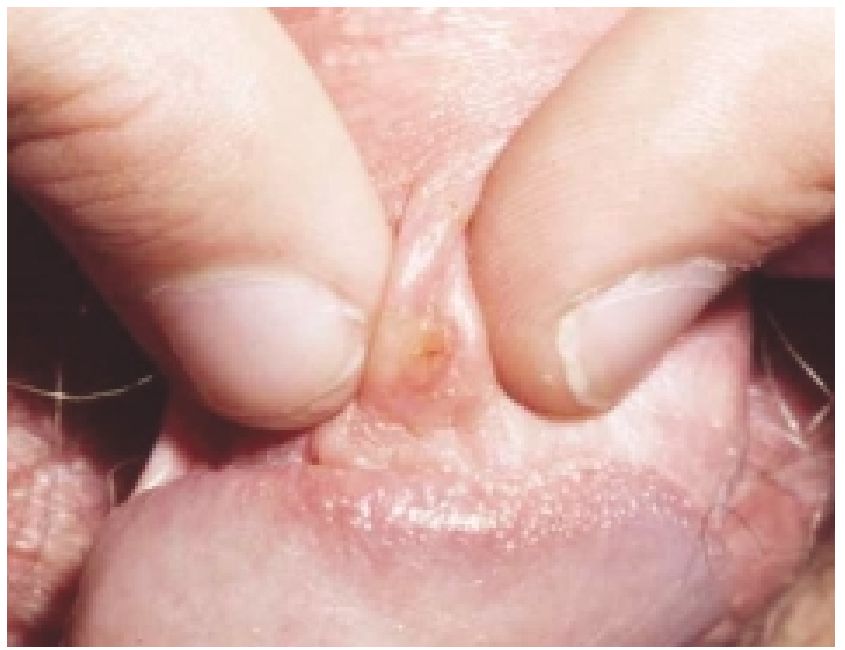

Figure 3: Primary syphilis - hard chancre

tated" syphilis). The so-called Rollet's [mixed] chancre is the result of a concomitant infection with Haemophilus ducreyi (chancroid). ${ }^{19}$

In locations with no possibility of a laboratorial diagnosis, the Brazilian Ministry of Health recommends a syndromic approach to ulcerated lesions with the simultaneous treatment of diagnostic possibilities. ${ }^{16}$

\section{SECONDARY SYPHILIS}

After a period of latency that can last from six to eight weeks, the disease becomes active again. The onset affects the skin and internal organs corresponding to the distribution of T. pallidum throughout the body.

Skin lesions (syphilids) occur by spurts and in a symmetrical fashion. They may be erythematous spots (syphilitic roseola) with an ephemeral duration. New spurts occur with papulous reddish-copper toned lesions that are rounded, with a flat surface, covered by slight scaling that is more intense peripherally (Biett's collarette). Involvement of palmar and plantar regions is typical (Figure 4). Sometimes there is intense scaling that gives the lesions a psoriasiform aspect. On the face, papules tend to group around the nose and mouth simulating seborrheic dermatitis (Figure 5). In black individuals, facial lesions take on annular and circinated configurations ("elegant syphilids") (Figure 6). In the inguinocrural region, papules subjected to friction and humidity may become vegetative and macerated, and they are rich in highly contagious treponemas (flat condyloma). On the oral mucosa, vegetative whitish-colored lesions upon an eroded base constitute mucous plaques that are also contagious.

In some patients, there may be diffuse alopecia, marked at the temporoparietal and occipital

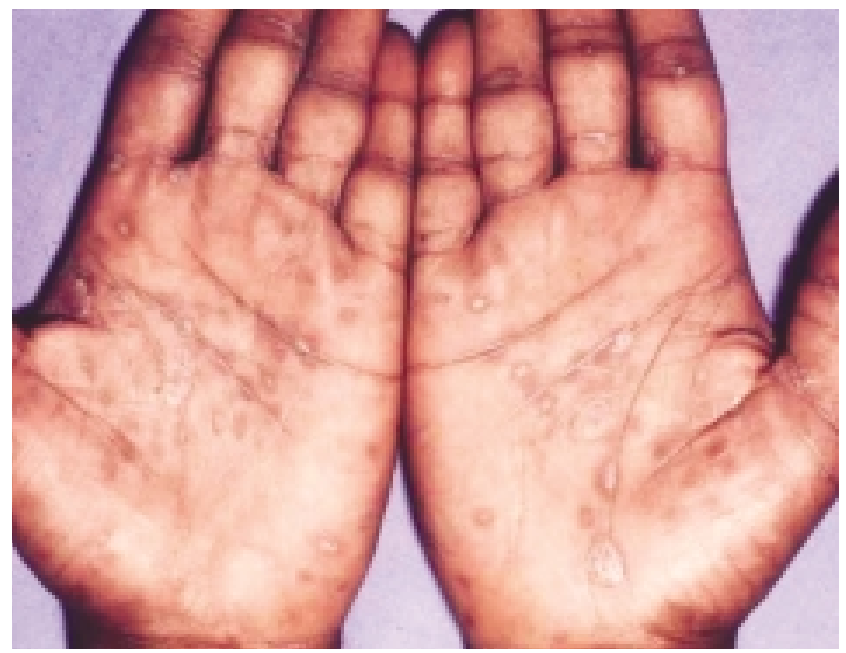

FIgURE 4: Secondary syphilis - palmar lesions

regions (patchy alopecia). There may also be a loss of eyelashes and the final portion of eyebrows. During this phase, there are rare cases described of pustulous, follicular, and lichenoid lesions.

Secondary syphilis is accompanied by generalized adenomegaly. General symptoms are mild and non-characteristic: malaise, asthenia, anorexia, low fever, headache, meningism, arthralgia, myalgia, periostitis, pharyngitis, hoarseness, hepatosplenomegaly, nephrotic syndrome, glomerulonephritis, neuritis of auditory nerve, and iridocyclitis.

The presence of popular and pustulous lesions that rapidly progress to necrosis and ulceration, many times with oyster-like or rupoid crusts and accompanied by intense general symptoms, represents a variant described as early malignant syphilis (Figure 7).

Hypochromic residual lesions ("Venus neckla-

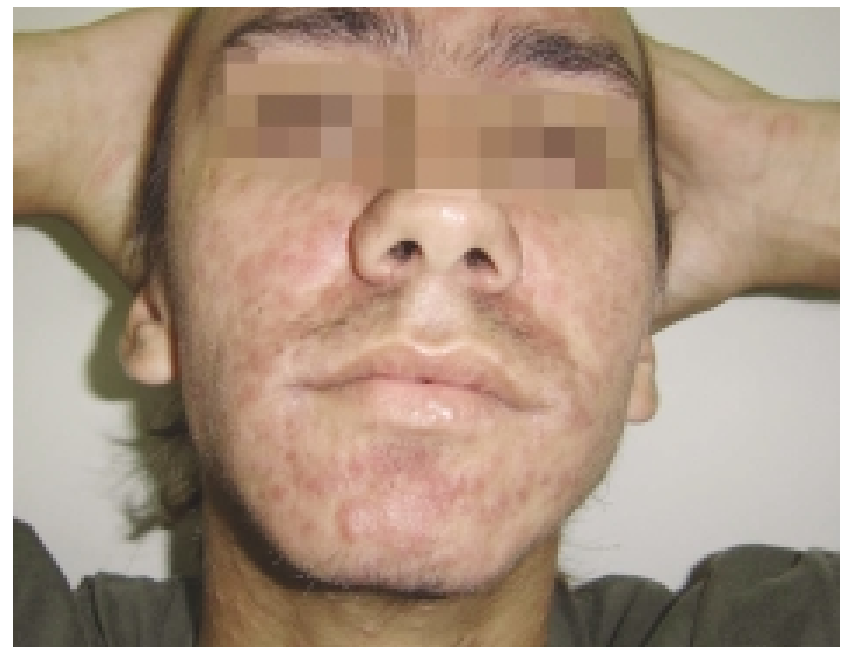

FIGURE 5: Secondary syphilis 


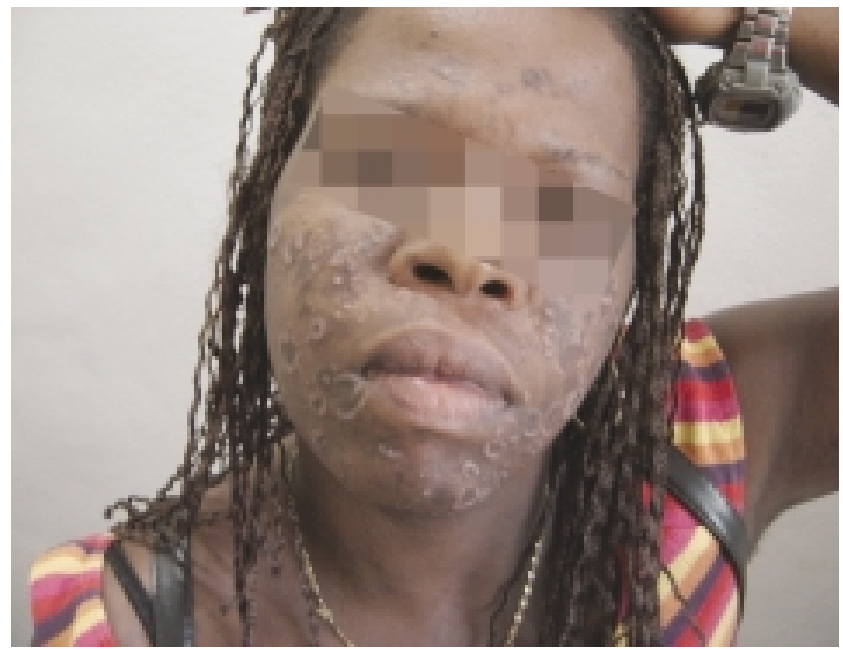

Figure 6: "Elegant" syphilis

ce") on the cervical region and anetodermic lesions, especially on the trunk, may follow secondary syphilis lesions. ${ }^{19 \cdot 21,23}$

The secondary phase progresses during the first and second years of the disease with flare-ups that recede spontaneously interspersed with increasingly longer periods of latency. Finally, the flare-ups disappear and a long period of latency sets in. Studies that accompany the natural evolution of syphilis have shown that one third of patients reach clinical and serological cure, and another third will progress without symptoms but maintain positive non-treponemic tests. In the last group, the disease will again manifest itself (tertiary syphilis). ${ }^{24,25}$

\section{TERTIARY SYPHILIS}

Patients in this phase develop localized lesions

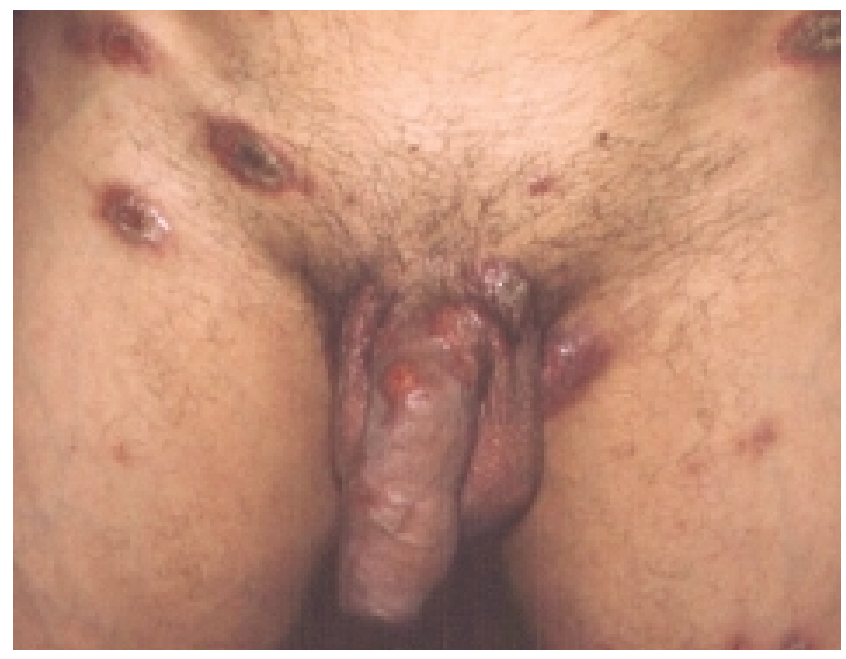

FiguRE 7: Early malignant syphilis that affect the skin and mucous membranes, and cardiovascular and nervous systems. Usually, the main characteristic of tertiary lesions is the formation of destructive granulomas (gummas) and an almost total absence of treponemas. Bones, muscles and liver may also be affected.

Skin lesions are nodules, tubers, nodular ulcerated plaques or tuberous circinated plaques and gummas. Lesions may be solitary or in small numbers, asymmetric, indurated with little inflammation, in arciform configurations and well-marked borders, polycyclic or forming circle segments (Figure 8). There may be tissue destruction and repair with or without ulceration, and a tendency towards central cure with peripheral extension, scar formation, and peripheral hyperpigmentation. In the tongue, involvement is insidious and painless, with thickening and indurations of the organ. Gummatous lesions may invade and perforate the palate and destroy the osseous base of the nasal septum. "Chancre redux" is the presence of a gumma at the site of the inoculation chancre, and "pseudochancre redux" is one solitary gumma located on the penis. ${ }^{19-21,23}$

\section{CARDIOVASCULAR SYPHILIS}

Symptoms generally develop between 10 and 30 years after the initial infection. The most common cardiovascular involvement is aortitis (70\%), especially of the ascending aorta. In most cases, this is asymptomatic. The main complications of aortitis are aneurism, aortic valve insufficiency, and coronary ostium stenosis. The diagnosis may be suspected by a chest X-ray that shows linear calcifications on the wall of the ascending aorta and dilation of the aorta. ${ }^{19,20,26}$

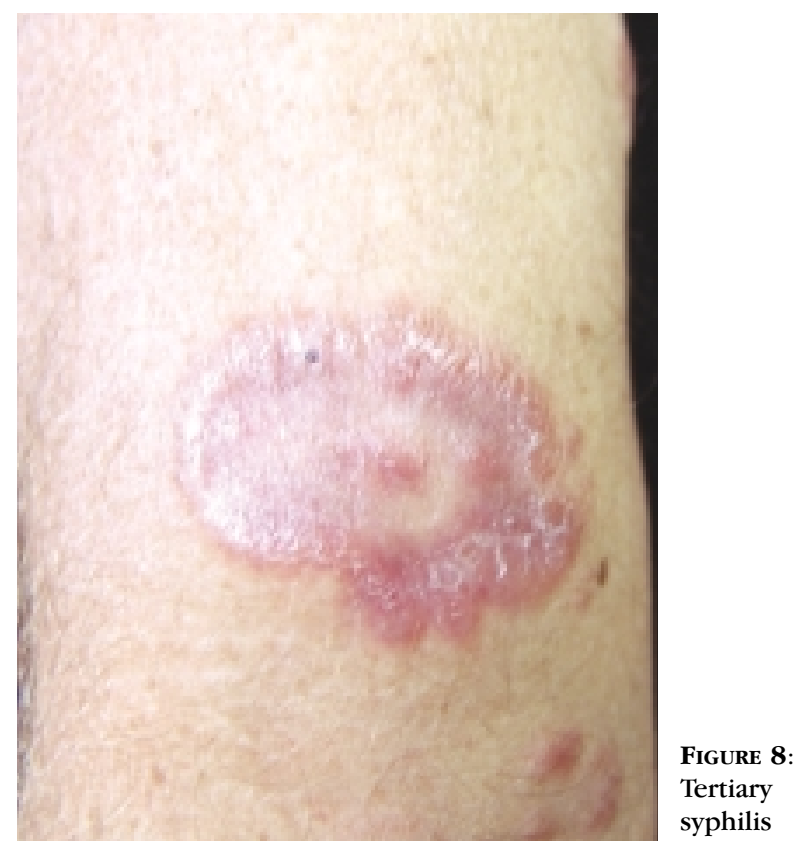




\section{NEUROSYPHILIS}

Meningeal invasion by the treponema is early, 12 to 18 months after infection, but disappears in $70 \%$ of cases without treatment. When the infection persists, a clinical picture of neurosyphilis is established that may be asymptomatic or symptomatic.

Asymptomatic neurosyphilis is defined as the presence of cerebrospinal fluid (CSF) abnormalities and no neurological signs or symptoms. It may never have clinical manifestations or it may evolve to one of the later neurological complications of the tertiary period. The earliest complications are acute meningeal symptoms that can occur during the secondary period, especially in patients infected by HIV, with classic meningeal symptoms. In meningovascular clinical pictures, neurosyphilis presents as diffuse encephalitis with focal signs, simulating a cerebrovascular accident.

Parenchymatous neurosyphilis appears later on and can present as a progressive general paralysis or evolve to tabes dorsalis. Lastly, there is a form of gummatous neurosyphilis with localized symptoms similar to cerebral or spinal tumors. ${ }^{19,20,27}$

\section{CONGENITAL SYPHILIS}

Congenital syphilis is the result of hematogenous dissemination of T. pallidum from an infected woman who was not treated or treated ineffectively to her fetus via the placenta (vertical transmission). Infection of the embryo can occur at any phase of gestation or stage of the maternal disease. The main determining factors for the possibility of transmission are the mother's stage of syphilis and the duration of intrauterine exposure of the fetus. Therefore, transmission is greater during the initial phases of illness when there are more spirochetes in circulation. Transmission rate is $70-100 \%$ during the primary and secondary phases, $40 \%$ in the latent phase, and $10 \%$ during the late latent phase. ${ }^{13}$

Fetal contamination may lead to miscarriages, fetal death, and neonatal death in $40 \%$ of infected fetuses, or birth of children with syphilis. Approximately $50 \%$ of children infected are asymptomatic at birth. There is also the possibility of direct transmission of the T. pallidum by contact of the newborn with maternal genital lesions in the birth canal.

Diagnosis of congenital syphilis depends on the combination of clinical, serological, radiological, and direct microscopy criteria. Even so, the Brazilian Ministry of Health has standardized its definition (Chart 1). When syphilis is manifested before two years of age, it is called early congenital syphilis; after two years of age, it is considered late congenital syphilis.

The skin and mucosal lesions of early congeni- tal syphilis may be present from birth, and the most common are macular exanthema on the face and limbs, bullous lesions, condyloma latum, and perioral and anal fissures. The nasal mucosa may present rhinitis with mucous and bloody discharge.

In other organs, hepatosplenomegaly, lymphadenopathy, osteochondritis, periostitis or osteitis, anemia, and fetal hydropsy may be noted.

In late congenital syphilis, when lesions are irreversible, the most distinctive are an olympic brow, high-arched palate, perioral fissures (rhagades), tibial bowing, Hutchinson's teeth and mulberry molars. Additionally, there may be keratitis, hearing loss, and mental retardation. A CSF test is recommended in all newborns that fit this definition. ${ }^{13}$

Radiographs of long bones are important because there are cases of infected asymptomatic newborns where the only alterations are radiological findings. ${ }^{13,16,19}$

\section{SYPHILIS AND HIV}

Interactions between syphilis and the HIV virus stem from the fact that both diseases are transmitted mainly by sexual contact and are important because ulcerated genital lesions raise the risk of contracting and transmitting the HIV virus. ${ }^{28,29}$

In the United States, analyses of studies on the seroprevalence of syphilis in HIV-positive patients identified positive results in $27.5 \%$ of males and in $12.4 \%$ of females. ${ }^{30}$

In HIV-infected patients, syphilis does not have an opportunistic behavior but shows less common clinical characteristics and an earlier and more frequent involvement of the nervous system.

In primary syphilis, the presence of multiple chancres is more common, as is the permanence of the inoculation lesion that may coexist with secondary syphilitic lesions. ${ }^{31-33}$

Oyster-like and ulcerated lesions of early malignant syphilis have been described more often ${ }^{31,34,35}$ as well as ocular and oral involvement. ${ }^{36}$

In most patients infected with the HIV virus, serological tests show results within the standard range found among non-infected patients. However, atypical results may appear. Titering may be high or low; fluctuations in test results and false-negatives may make the laboratory diagnosis difficult. ${ }^{35,37}$

\section{LABORATORY DIAGNOSIS}

The laboratory diagnosis of syphilis and the choice of the most appropriate laboratory tests should take into consideration the evolutionary phase of the disease. In primary syphilis and in some secondary phase lesions the diagnosis may be direct, i.e., by demonstrating the presence of treponema. 
Chart 1: Definitions for congenital syphilis cases

- Confirmed case: when the T. pallidum or its genetic material is physically identified in samples of lesions, amniotic fluid, umbilical cord or tissues from autopsy

- Presumptive case: when at least one of the following parameters is present:

1 - Newborn or child whose contaminated mother was not treated or was treated inadequately

2 - Newborn or child with a positive treponemic test and some of the following alterations: evidence of congenital syphilis on physical examination; radiological changes; positive VDRL in CSF; high content of proteins or leukocytosis in CSF in the absence of other causes; IgM positive for syphilis

3 - Syphilitic stillborn - fetal death in a gestation of more than 20 weeks or a fetus weighing more than $500 \mathrm{~g}$ born of a syphilitic mother who was not treated or was treated inadequately

Source: Diretrizes para o controle da sífilis congênita. Brasília: MS/PN de DST/Aids, 2005

Serology may be used as of the second or third week after the chancre appears, when antibodies start to be detected. ${ }^{19}$

\section{DIRECT TESTS}

Direct tests demonstrate the presence of T. pallidum and are definitive since they are not subject to interference of crossed mechanisms, that is, falsepositive results. They are indicated in the initial phase of the illness, when microorganisms are numerous. They can be indicated in primary and secondary syphilis in cases with bullous lesions, mucous plaques, and condylomas. The use of material from the oral mucosa should take into account the difficulty in differentiating between the treponema and other saprophyte spirochetes of the mouth, except when direct immunofluorescence methods are used. ${ }^{19,21}$

\section{A - DARK-FIELD MICROSCOPY}

This test consists of a direct examination of lymph from the lesion. The specimen is seen under the microscope with a dark-field condenser enabling visualization of the live mobile $T$. pallidum with indirect light. It is considered a quick, low-cost, and definitive test. Sensitivity varies from 74 to $86 \%$, and can reach $97 \%$ depending on the analyzer's experience. ${ }^{38,39}$

\section{B - DIRECT EXAMINATION WITH STAINED MATERIAL}

Methods used are those of FontanaTribondeau, Burri, Giemsa, and Levaditi.

With the Fontana-Tribondeau method, after lymph is collected, it is smeared on a slide with the addition of silver. Silver impregnates the treponema wall and makes it visible. Burri's method uses China ink (India ink).
In Giemsa staining, T. pallidum colors are very pale and it is difficult to visualize the spirochete; Levaditi's method uses silver in histological slices. All staining methods are inferior to the use of the darkfield microscopy. ${ }^{21}$

\section{C - DIRECT IMMUNOFLUORESCENCE}

This is a highly specific test with sensitivity greater than $90 \%$. It practically eliminates errors in interpretation with saprophyte treponemas. It is called DFA-TP (direct fluorescent-antibody testing for $T$. pallidum).

\section{SEROLOGY TESTS}

In the body, the T. pallidum promotes the development of two types of antibodies: reagins (nonspecific IgM and IgG antibodies against cardiolipin), originating non-treponemic tests, and specific antibodies against $T$. pallidum, which originated the treponemic tests. Non-treponemic tests are useful for screening population groups and monitoring treatment, while treponemic evaluations are used for diagnosis confirmation.

\section{A - NON-TREPONEMIC TESTS}

The first tests for syphilis diagnosis were complement fixation reactions. Wassermann and Khan reactions used material extracted from tissues that were difficult to standardize and ultimately gave way to more purified antigens, such as the VDRL (Venereal Disease Research Laboratory) that uses an antigen made up of lecithin, cholesterol and purified cardiolipin. Cardiolipin is a component of the plasmatic membrane of mammals that is released after cell damage and is also present in T. pallidum wall.

The VDRL test turns positive between five and six weeks after infection and between two and three 
weeks after the chancre appears. Consequently, it may be negative in primary syphilis. In secondary syphilis, it proves to be highly sensitive, and in late forms of the disease, its sensitivity diminishes.

This reaction is not specific, and it can be positive in other treponematoses and in several other situations. These false-positive reactions may be divided into transitory and persistent. The transitory results turn negative in six months (malaria, pregnancy, infectious mononucleosis, viroses, tuberculosis, and others). Persistent reactions remain positive beyond six months (lepromatous leprosy and autoimmune diseases, such as lupus). Titers are usually high in treponematoses (over 1/16), and can even exceed $1 / 512$.

False-negative results in secondary syphilis (1\% to $2 \%$ ) are due to an excess of antibodies (prozone effect). These cases could be avoided with the use of greater serum dilutions.

Rapid non-treponemic tests have a vital significance in syphilis control. One of them is the rapid plasma reagin test (RPR), the most widely used and performed by a finger puncture. It was the first screening serology test to dispense the use of conventional laboratory equipment and it provides a result in 60 minutes. It is also quantifiable, but not comparable with the titers obtained in the VDRL test.

Non-treponemic tests can be titered and thus are important in the control of cure. Persistence of low titers in patients who were correctly treated is called a serological scar and can persist for many years. ${ }^{19,20,40,41}$

\section{B - TREPONEMIC TESTS}

Treponemic tests use $T$. pallidum as an antigen. They are used to confirm the reactivity of nontreponemic tests and in cases where non-treponemic tests have low sensitivity, such as in late syphilis. They turn positive a little earlier than non-treponemic tests. In $85 \%$ of people treated successfully, the results remain reactive for many years or even for their lifetime.

The TPI (treponema immobilization test) was the first treponemic test developed. It utilizes as antigens live virulent treponemas obtained from testicular syphilomas of rabbits. In spite of being specific, the reaction is difficult and costly to perform, and it is used strictly in research laboratories. ${ }^{40}$

The fluorescent treponemic antibody (FTA) test has undergone modifications in its dilution and has improved its sensitivity and specificity, resulting in the FTA-ABS. It is quick and low-cost, but requires a fluorescent microscope. In autoimmune diseases and other treponematoses there may be false-positive results. ${ }^{1921}$ TPHA and MHA-TP are hemagglutination tests. MHA-TP is based on passive hemagglutination of sensitized erythrocytes of sheep..$^{41,42}$ In untreated syphilis, its sensitivity is equal to that of FTA-ABS, except in initial primary syphilis where the latter is more sensitive. ${ }^{21}$

Treponemic enzymatic immunoassay (EIA) and Western-blot tests are confirmatory methods. EIA is an alternative test that combines VDRL with TPHA. The laboratorial process is automated and furnishes an objective reading of the results. ${ }^{43-45}$ The Western-blot method identifies antibodies against IgM and IgG immunodeterminants with molecular masses $(15 \mathrm{kDa}, 17 \mathrm{kDa}, 44 \mathrm{kDa}$ and $47 \mathrm{kDa}){ }^{41,46}$ So far, these tests have shown a high level of sensitivity and specificity in all phases of syphilis, but are being used primarily in research projects. ${ }^{40}$

In the early 1990's, two PCR techniques were described and adopted, especially for detecting treponemic antigens in primary syphilis, with high levels of sensitivity and specificity. PCR is also extremely useful in the diagnosis of congenital syphilis and neurosyphilis. The DNA of the T. pallidum is detected with the use of primers for the protein-codifying gene with a molecular weight of $47 \mathrm{kD}$. Amplification of T. pallidum RNA is more sensitive for demonstrating the viability of the treponema, and utilizes primers that amplify a region with $366 \mathrm{bp}$ of the gene $16 \mathrm{~S} \mathrm{r}$ RNA. ${ }^{41,47-50}$

\section{RAPID TREPONEMIC TESTS}

These were developed from agglutination tests are very important as diagnostic aides in light of their immediate readings. The immunochromatographic assay is the most effective. The immunochromatographic test allows visual and qualitative detection of antibodies (IgG, IgM and IgA) against a recombined antigen from $47-\mathrm{kDa}$ of the T. pallidum in whole blood, serum, and plasma of humans. The blood can be collected by finger puncture. Reading is performed between 5 and 20 minutes later. Sensitivity and specificity of the test are $93.7 \%$ and $95.2 \%$, respectively, and have proved to be superior to those of RPR in preliminary studies. ${ }^{51}$

Nevertheless, this test should not be used as an exclusive criterion for the $T$. pallidum infection. These tests may substitute rapid non-treponemic tests, especially as screening assessments. ${ }^{51-55}$

\section{CEREBROSPINAL FLUID EXAMINATION}

Examination of the cerebrospinal fluid (CSF) should be indicated in patients with a serological diagnosis of recent or late syphilis with neural symptoms and in patients who have maintained serological blood reactions with high titers after appropriate treatment. The use of lumbar puncture in cases of late latent syphilis (more than one year duration or 
unknown duration) and in HIV-positive patients regardless of the stage of the disease has been questioned, although it continues as a recommendation in control manuals. ${ }^{16,56}$

No single serological test is safe in the diagnosis of neurosyphilis.

Diagnosis is made by combining the positive results of the serology test, an increase in cellularity (more than 10 lymphocytes $/ \mathrm{mL}$ ), and proteins in the CSF (over $40 \mathrm{mg} / \mathrm{dL}$ ).

VDRL is the test recommended for examining cerebrospinal fluid. The use of VDRL in CSF shows a low sensitivity (30-47\% false negative) and high specificity. The FTA-ABS can be positive when antibodies pass to the CSF by blood diffusion in patients with syphilis. However, it is a highly sensitive test, and neurosyphilis can be excluded by a negative FTA-ABS evaluation. In HIV-positive patients, the CSF examination should take into consideration that changes in cell counts and in the isolated values of proteins can be attributed to neurological effects of the HIV virus..$^{19,20,27}$

\section{CONGENITAL SYPHILIS}

The diagnosis of congenital syphilis is confirmed by direct tests with the identification of T. pallidum in lesions, body fluids, or tissues. Serological tests can be done with umbilical cord blood and peripheral blood of newborns. In the absence of lesions, the diagnosis should consider the fact that maternal antibodies can pass to the fetus without infection. In this case, periodic quantitative serology evaluations are necessary (they turn negative within six months after birth); FTAABS-IgM can also be used since the IgM does not go through the placenta barrier and is diagnostic when it is positive. As to VDRL, the diagnosis of congenital syphilis is made when the results on the newborn are four times or more the maternal titer. ${ }^{13}$

\section{HISTOPATHOLOGY}

This is not routinely used for diagnosis. Nevertheless, as its findings are suggestive, the diagnosis of syphilis may be suspected by the pathologist and it is necessary to have serological confirmation. The basic pathology in all stages includes edema, endothelial cell proliferation, and perivascular inflammatory infiltrate with lymphocytes and plasmocytes. During the primary and secondary phases, vessels are dilated, thickened, and there is a proliferation of endothelial cells. An inflammatory infiltrate of mononuclear cells and plasmocytes with a perivascular location is the most distinctive alteration. In the late phases of secondary syphilis and in tertiary syphilis, besides vascular changes, there may be epithelioid and giant cell granulomas with or without central necrosis. $^{57}$

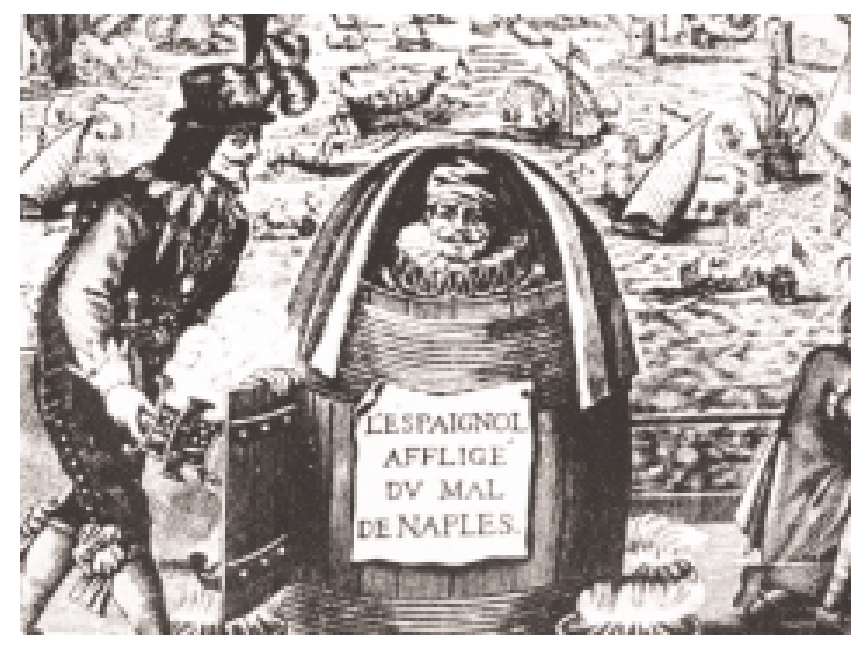

FIGURE 9: Syphilis - treatment - stufa sicca

\section{RADIOGRAPHIC EXAMINATION}

In cases of suspected congenital syphilis, X-rays of long bones may offer diagnostic support. The most characteristic modifications are osteochondritis, periostitis and osteomyelitis. In some cases, these may be the only alterations in the newborn. ${ }^{13}$

\section{TREATAMENT}

Mercury, arsenic, bismuth, and iodides were used initially in an attempt to treat syphilis, but they showed low efficacy, toxicity, and operational difficulties. Treatments inspired by the low resistance of $T$. pallidum to heat that recommended increasing body temperature by physical means, such as hot steam baths, or the inoculation of plasmodium into the circulation (malariotherapy) were also non-effective (Figure 9).

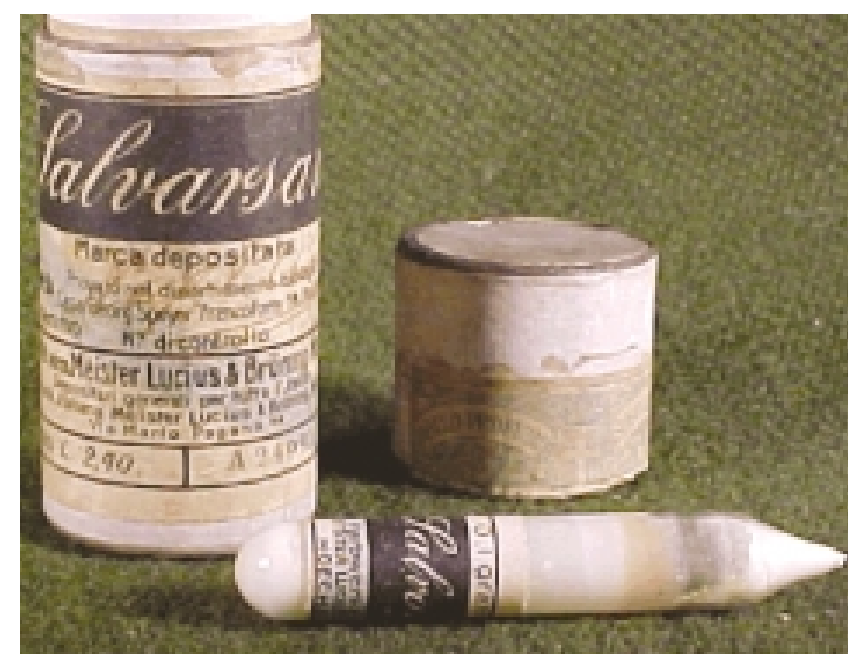

FIGURE 10: Syphilis treatment - salvarsan 
The growing concern with the increase in cases mobilized physicians and scientists. Among them, Paul Erlich, who, in 1909, after 605 attempts of modifying arsenic, synthesized a compound that was called compound 606 or salvarsan, the first chemotherapy substance in the history of medicine ${ }^{18}$ (Figure 10).

In 1928, the discovery of the bactericide power of the Penicilium notatus fungus, which was noticed by Fleming, would modify the history of syphilis and of other infectious diseases. Penicillin acts by interfering in the synthesis of the peptidoglycan, a cell wall component of the T. pallidum. This results in the inflow of water into the treponema, leading to its destruction.

In 1943, Mahoney demonstrated that penicillin is active in all stages of syphilis. Sensitivity of the treponema to the drug and the ready response with regression of primary and secondary lesions after one single dose are some advantages that remain even today. Penicillin continues as the drug of choice, and to date there have been no documented cases of resistance.

The effective blood concentration is $0.03 \mu / \mathrm{cm}^{3}$ and it should be maintained for a time longer than that needed for treponema division. Therefore, the choice falls on benzathine penicillin. Chart 2 shows the plan recommended by the Brazilian Ministry of Health. ${ }^{56}$

For neurosyphilis, the drug of choice is crystalline penicillin because of its capacity to go through the blood brain barrier. The recommended dose varies from three to $4,000,000 \mathrm{IU}$, intravenously, every four hours, for a total of 18 to $24,000,000$ IU/day for 10 to 14 days. ${ }^{56}$

Most cases of reactions to penicillin are benign in nature, and anaphylactic reactions occur in 10 to 40 per 100,000 injections given, with two deaths per 100,000 . In cases of allergy to penicillin, the intradermal test should be done; in proven cases, desensitizing with oral penicillin $\mathrm{V}$ should be carried out according to recommendations of the Brazilian Ministry of Health. ${ }^{16}$ If these measures are not possible, other drugs should be used. Doxycyclin may be utilized at the dose of $100 \mathrm{mg} /$ day, tetracycline and erythromycin (stearate) at $500 \mathrm{mg}$ every six hours, all for a period of 15 days in recent syphilis and 30 days in late syphilis. Penicillin is the only drug considered effective in treating pregnant women..$^{58,59}$ The therapeutic regimen should be chosen according to the stage of syphilis with the same doses as those of standard treatment. Patients allergic to penicillin should be desensitized and treated with penicillin. ${ }^{16,56}$

Treatment of congenital syphilis should be done as per charts 3 and 4 .

Accompaniment of reductions in patients'
CHART 2: Treatment regimen for syphilis

Recent syphilis: primary syphilis

Benzathine penicillin 2,400,000 IU, IM, single dose

Recent syphilis: secondary syphilis or recent latent (less than one year)

Benzathine penicillin $4,800,000 \mathrm{IU}$, IM, in two weekly doses of 2,400,000 IU each

Late syphilis: tertiary syphilis, late latent syphilis (more than one year) and latent syphilis of unknown duration

Benzathine penicillin 7,200,000 IU, IM, in three weekly

doses of 2,400,000 IU each

Source: Guia de controle das DST. Brasília: MS/PN de DST/Aids, 1999.

titers should be done every three months, and in the second year, every six months.

\section{OTHER DRUGS}

The discomfort of the intramuscular injection of benzathine penicillin affects compliance, hence other treatment options are sought. Two recently tested drugs are ceftriaxone and azithromycin. Both proved to be active, but none is superior to penicillin; therefore, they should be considered as a second line of treatment. ${ }^{18}$

Ceftriaxone showed activity in an animal model and in small groups of patients, but has a high rate of re-treatments in HIV-positive patients. ${ }^{18}$

The response to azithromycin in rabbits and in small groups of patients, as well as the possibility of a single oral dose, stimulated the prophylactic use of the drug. However, high rates of resistance to azithromycin were observed. Genetic studies confirmed resistant mutants in $28 \%$ of material examined by PCR. ${ }^{60}$

The identification of resistant strains shows that the use of these antibiotics should be vigilant, especially in individuals with the HIV virus. ${ }^{60.62}$

\section{JARISCH-HERXHEIMER REACTION}

Jarish and Herxheimer described this reaction with mercury compounds use before the discovery of penicillin. It can occur at all stages of syphilis after patients have been treated. Frequency of the reaction varies between $30 \%$ and $70 \%$ in cases of primary and secondary syphilis. ${ }^{18}$

The etiolopathogenesis is attributed to lipoproteic antigens, which have inflammatory activity and are released from the T. pallidum wall after the death of the treponemas.

The reaction was reported in diseases caused 
CHART 3: Congenital syphilis treatment regimen

\section{NEONATAL PERIOD}

A - A- In newborns (NB) of non-treated or inadequately treated syphilitic mothers, regardless of NB VDRL result, perform: X-rays of long bones, lumbar puncture (when this is not possible, treat the case as neurosyphilis), and other tests, whenever clinically indicated. Treat according to the following criteria:

A1 - If there are clinical and/or serological and/or radiological alterations, treatment should be done with crystalline penicillin at $50,000 \mathrm{IU} / \mathrm{kg} / \mathrm{dose}$, IV, twice a day, if infant is less than one week old, and three times a day, if infant is more than one week old, for 10 days; or penicillin G procaine at 50,000 IU/kg, IM, for 10 days.

A2 - If there are CSF alterations, treatment should be done with crystalline penicillin G, 50,000 IU/ kg/ dose, IV, twice a day, if the infant is less than one week old, and three times a day, if the infant is more than one week old, for 14 days. A3 - - If there are no clinical, radiological and/or CSF alterations, and NB serology is negative, treat with benzathine penicillin G, IM, at a single dose of $50,000 \mathrm{IU} / \mathrm{kg}$. Accompaniment is mandatory; when accompaniment is not possible, the NB should be treated as per the A1 regimen.

B - In NB whose mothers were adequately treated, perform VDRL tests in sample of NB peripheral blood; if it is reagent with a titer greater than the mother's and in the presence of clinical alterations, perform X-rays of long bones and CSF analysis. And:

B1 - If there are radiological alterations without CSF changes, treatment should be given with penicillin $\mathrm{G}$ crystalline, $50,000 \mathrm{IU} / \mathrm{kg} /$ dose, two to three times a day depending on the age, for 10 days; or penicillin $\mathrm{G}$ procaine $50,000 \mathrm{IU} / \mathrm{kg}$, IM, for 10 days (A1 regimen).

B2 - If there are CSF changes, treatment should follow the A2 regimen.

C - If the NB is not reagent or is reagent with a titer equal to or lower than the mother's and the NB is also asymptomatic and the long bones X-ray shows no changes, perform only out-patient follow-up.

Source: Diretrizes para o controle da sífilis congênita. Brasília: MS/PN de DST/Aids, 2005.

CHART 4: Algorithm for laboratory diagnosis and treatment of congenital syphilis

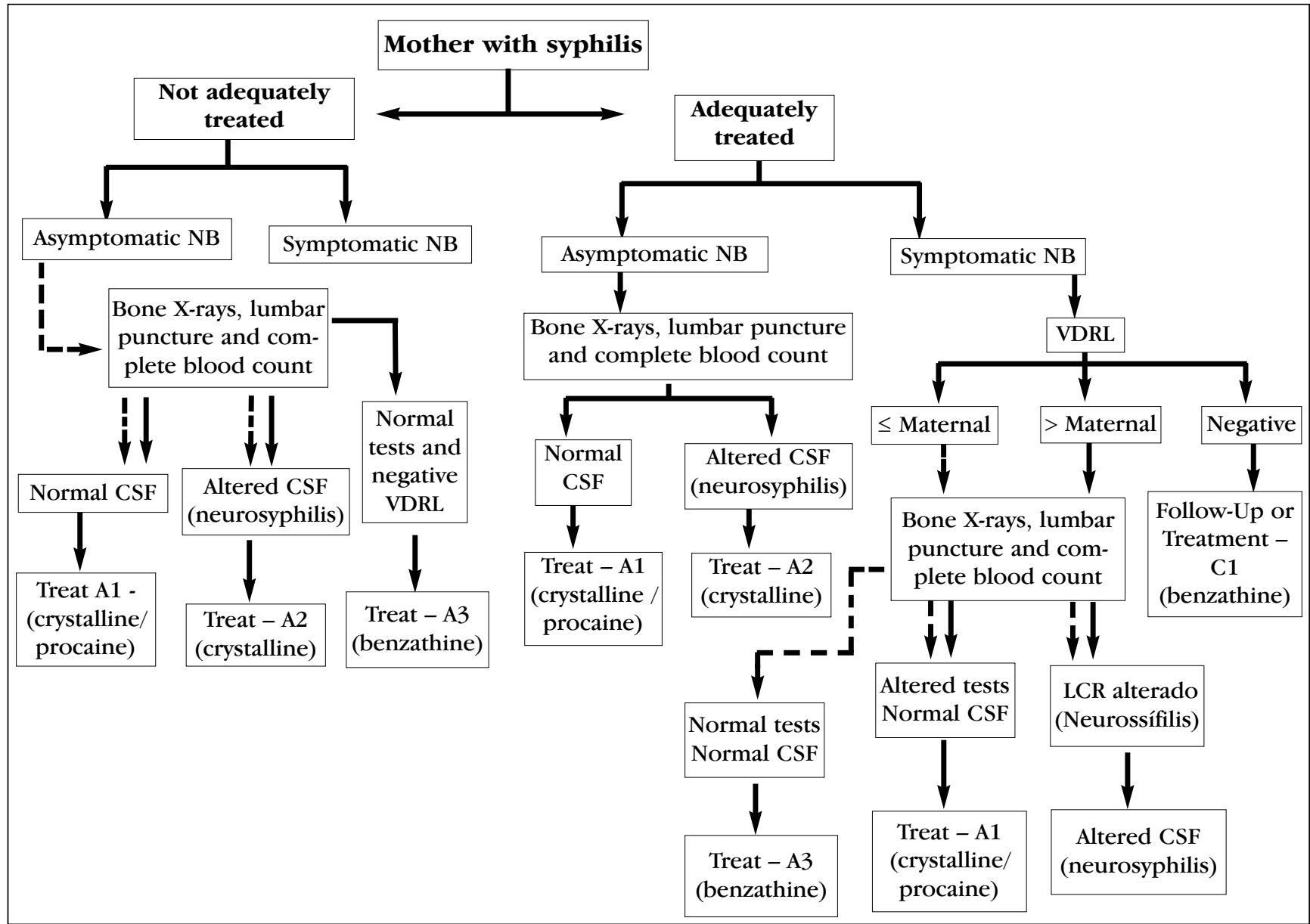

Source: Diretrizes para o controle da sífilis congênita. Brasília: MS/PN de DST/Aids, 2005. 
by spirochetes, such as leptospirosis ${ }^{63}$ and borrelioses. ${ }^{64}$ Clinically, it consists of an exacerbation of lesions, systemic symptoms (fever, chills, headache, myalgia, arthralgia), and laboratory alterations (leukocytosis with lymphopenia). Onset is within 4 and 12 hours after treatment. Besides penicillin, this reaction was described with erythromycin, amoxicillin, tetracycline, and quinolones. ${ }^{18,65}$ The reaction picture recedes within six to 12 hours. Treatment is symptomatic with analgesic and antipyretic drugs. The prior use of corticosteroids in order to avoid the reaction is debatable. In pregnant women, the reaction may lead to a premature infant and fetal death, especially when the fetus is infected. . $^{18,66,67}$

\section{PREVENTION AND CONTROL}

The objective of syphilis control is to interrupt the chain of transmission and prevention of new cases.

\section{REFERENCES}

1. Rivitti EA. Sífilis. In: Machado-Pinto J. Doenças infecciosas com manifestações dermatológicas. Rio de Janeiro: Medsi; 1994.

2. Goh BT. Syphilis in adult. Sex Transm Infect. 2005;81: 448-52.

3. Hopkins S, Lyons F, Coleman C, Courtney G, Bergin C, Mulcahy F. Resurgence in infectious syphilis in Ireland: an epidemiological study. Sex Transm Dis. 2004;31:317-21.

4. Marcus U, Kollan C, Bremer V, Hamouda O. Relation between the HIV and the re-emerging syphilis epidemic among MSM in Germany: an analisis based on anonymous surveillance data. Sex Transm Dis. 2005;81:456-7.

5. Dilley JW, Klausner JD, McFarland W, Kellogg TA, Kohn $\mathrm{R}$, Wong $\mathrm{W}$, et al. Trends in primary and secondary syphilis and HIV infections in men who have sex with men - San Francisco and Los Angeles, California. 19982002. MMWR Morb Mortal Wkly Rep. 2004;53:575-8.

6. Buchacz K, Greenberg A, Onorato I, Janssen R. Syphilis epidemics and human immunodeficiency virus (HIV) incidence among men who have sex with men in the United States: implications for HIV prevention. Sex Transm Dis. 2005;32(10 Suppl):S73-9.

7. Wong ML, Chan RKW, Chua WL, Wee S. Sexually transmitted
Avoiding transmission of the disease consists of detecting and initiating early and appropriate treatment of the patient and his/her partner(s). In detecting cases, the use of the rapid test in partners of patients or pregnant women may be important. Adequate treatment consists of using penicillin as a first choice and at the appropriate doses. In special situations, such as a localized increase in cases, prophylactic treatment may be considered.

Prevention of new cases should have a strategy of information on the disease and its prevention for the general population and specifically for the more vulnerable populations (prostitutes, intravenous drug users, etc.). Patient counseling is important in order to show the need for communication with his/her partner and instigate the use of condoms in sexual relations. Continuing education for health professional teams completes this set of measures for prevention and control of syphilis. ${ }^{16,68}$

diseases and condoms use among female freelance and brothel-based sex workers in Singapore. Sex Transm Dis. 1999;26:593-600.

8. Mgnone CS, Passey ME, Anang J, Peter W, Lupiwa T, Russell DM, et al. Human immunodeficiency virus and other sexually transmitted diseases in two major cities in Papua New Guinea. Sex Transm Dis. 2002;29:265-70.

9. Centers for disease control and prevention (CDC). Sexually transmitted disease surveillance 2004. Atlanta, GA: US Department of Health and Human Services, Centers for Diseases Control and Prevention; 2005.

10. Temmerman M, Gichangi P, Fonck K, Apers L, Claeys P, Van Renterghem L, et al. Effect of a syphilis control programme on pregnancy outcome in Nairobi, Kenya. Sex Transm Infect. 2000;76:207-11.

11. Azeze B, Fantahun M, Kidan KG, Haile T. Seroprevalence of syphilis amongst pregnant women attending antenatal clinics in a rural hospital in north west Ethiopia. Genitourin Med. 1995;71:347-50.

12. Leroy V, De Clercq A, Ladner J, Bogaerts J, Van de Perre P, Dabis F. Should screening of genital infection be part of antenatal care in areas of high HIV prevalence? A prospective cohort study from Kigali, Rwanda, 19921993. Genitourin Med. 1995;71:207-211. 
13. Brasil. Ministério da Saúde. Diretrizes de Controle da Sífilis Congênita. Brasília (DF): Ministério da Saúde; 2005. p. 7-53.

14. Codes JS, Cohen DA, Melo NA, Teixeira GG, Leal Ados S, Silva Tde J, et al. Screening of sexually transmitted diseases in clinical and non-clinical settings in Salvador, Bahia, Brazil. Cad Saude Publica. 2006;22:325-34.

15. Szwarcwald CL, de Carvalho MF, Barbosa Junior A, Barreira D, Speranza FA, de Castilho EA. Temporal trends of HIV-related risk behavior among Brazilian military conscripts. Clinics. 2005;60:367-74.

16. Brasil. Ministério da Saúde. Manual de Controle das Doenças Sexualmente Transmissíveis. 3. ed. Brasília (DF): Ministério da Saúde; 1999. p. 44-54.

17. Miranda AE, Alves MC, Neto RL, Areal KR, Gerbase AC. Seroprevalence of HIV, hepatitis B virus, and syphilis in womens at their first visit to public antenatal clinics in Vitoria, Brazil. Sex Transm Dis. 2001;28:710-3.

18. Singh AE, Romanowski B. Syphilis: review with emphasis on clinical,epidemiologic and some biologic features. Clin Microbiol Rev. 1999;12:187-209.

19. Azulay MM, Azulay DR. Treponematoses. In: Azulay e Azulay. Dermatologia. 3.ed. Rio de Janeiro: Guanabara Koogan; 2004. p. 240-51.

20. Sanchez MR. Syphilis. In: Fitzpatrick's Dermalotogy in general medicine. 6. ed. USA: McGraw Hill; 2003. p. 2163-88.

21. Rivitti EA. Súfilis Adquirida. In: Walter Belda Júnior. Doenças Sexualmente Transmissíveis. São Paulo: Atheneu; 1999. p. 9-21.

22. Garnett GP, Aral SO, Hoyle DV, Cates W Jr, Anderson RM. The natural history of syphilis. Implications for the transmission dynamics and control of infection. Sex Transm Dis. 1997;24:185-200.

23. Sampaio SAP, Rivitti EA. Sífilis e outras Doenças Sexualmente Transmissíveis. In: Dermatologia. 2. ed. São Paulo: Artes Médicas; 2001. p. 489-500.

24. Gjestland T. The Oslo of untreated syphilis: an epidemiological investigation of the natural course of the syphilitic infection based upon a re-study of the Boeck-Bruusgaard material. Acta Derm Venereol. 1955; 35(Suppl 34):S3-368.

25. Rockwell DH, Yobs AR, Moore MB Jr. The Tuskegee study of untreated syphilis; the 30th year of observation. Arch Intern Med. 1964;114:792-8.

26. O' Regan AW, Castro C, Lukehart SA, Kasznica JM, Rice PA, Joyce-Brady MF. Barking up the wrong tree? Use of polymerase chain reaction to diagnose syphilic aortitis. Thorax. 2002;57:917-8.

27. Nitrini R, Souza MC. Neurossífilis. In: Walter Belda Júnior. Doenças Sexualmente Transmissíveis. São Paulo: Atheneu; 1999. p. 31-44.

28. Fleming DT, Wasserheit JN. From epidemiological synergy to public health policy and practice: the contribution of other sexually transmitted diseases to sexual transmission of HIV infection. Sex Transm Infect. 1999;75:3-17.

29. Wasserheit JN. Epidemiological synergy: interrelationships between human immunodeficiency virus infection and other sexually transmitted diseases. Sex Trans Dis. 1992;19:61-77.

30. Blocker ME, Levine WC, Stlouis ME. HIV prevalence in patients with syphilis. Sex Transm Dis. 2000;27:53-9.

31. Rompalo AM, Joesoef MR, O'Donnell JA, Augenbraun M, Brady W, Radolf JD, et al. Clinical manifestation of early by HIV status and gender: results of the syphilis and HIV study. Sex Transm Dis. 2001;28:158-65.

32. Hutchinson CM, Hook EW, Shepard M, Verley J, Rompalo AM. Altered clinical presentation of early syphilis in patients with human immunodeficiency virus infection. Ann Intern Med. 1994;121:94-100.

33. Proença NG, Freitas THP, Gagliardi R, Alonso FF. Aspectos incomuns da sífilis em pacientes com síndrome da imunodeficiência adquirida. An Bras Dermatol. 1991;66:5-6.

34. Romero-Gimenez MJ, Suarez Lozano I, Fajardo Pico JM, Baron Franco B. Malignant syphilis in patient with human immunodeficiency virus (HIV): case report and literature review. An Med Interna. 2003;20:373-6.

35. Criado PR, Segurado AC, Valente NYS, Sotto M, Juang JM. Sífilis secundária pustulosa em paciente HIV positivo: relato de caso. An Bras Dermatol.1996;71:217-21.

36. Laskaris G. Oral manifestations of HIV disease. Clin Dermatol. 2000;18:447-55.

37. Schofer H, Imhof M, Thoma-Greber E, Brockmeyer NH, Hartmann M, Gerken G, et al. Active syphilis in HIV infection: a multicentre retrospective survey. The German AIDS Study Group(GASS). Genitourin Med. 1996;72:176-81.

38. Palmer HM, Higgins SP, Herring AJ, Kingston MA. Use of PCR in the diagnosis of early syphilis in the United Kingdom. Sex Transm Infect. 2003;79:479-83.

39. Young $H$. Guidelines for serological testing for syphilis. Sex Transm Infect. 2000;76:403-5.

40. Rotta O. Diagnóstico sorológico da sífilis. An Bras Dermatol. 2005;80:299-302.

41. Larsen SA, Steiner BM, Rudolph AH. Laboratory, diagnosis and interpretation of tests of syphilis. Clin Microbiol Rev. 1995;8:1-21.

42. Sato T, Kubo E, Yokota M, Kayashima T, Tomizawa T. Treponema pallidum specific IgM haemagglutination test for serodiagnosis of syphilis. Br J Vener Dis. 1984; 60:364-70.

43. Ebel A, Bachelart L, Alonso JM. Evaluation of a New Competitive Immunoassay (BioElisa Syphilis) for Screening for Treponema pallidum Antibodies at Various Stages of Syphilis. J Clin Microbiol. 1998;36: 358-61.

44. Woznicova V, Votava M. Contradictory results of passive hemagglutination and immunoenzyme tests in the 
determination of specific immunoglobulin $G$ in serodiagnosis of lues. Cas Lek Cesk. 2002;141:152-5.

45. Castro R, Prieto ES, Santo I, Azevedo J, Exposto Fda L. Evaluation of an enzyme immunoassay technique for detection of antibodies against treponema pallidum. J Clin Microbiol. 2003;41:250-3.

46. Sato NS, Suzuki T, Ueda T, Watanabe K, Hirata RD, Hirata MH. Recombinant antigen-based immuno-slot blot method for serodiagnosis of syphilis. Braz J Med Biol Res. 2004;37:949-55.

47. Burstain JM, Grimpel E, Lukehart SA, Norgard MV, Radolf JD. Sensitive detection of Treponema pallidum by using the polymerase chain reaction. J Clin Microbiol. 1991;29:62-9.

48. Wicher K, Noordhoek GT, Abbruscato F, Wicher V. Detection of Treponema pallidum in early syphilis by DNA amplification. J Clin Microbiol. 1992;30:497-500.

49. Centurion-Lara A, Castro C, Shaffer JM, Van Voorhis WC, Marra CM, Lukehart SA. Detection of Treponema pallidum by a sensitive reverse transcriptase PCR. J Clin Microbiol. 1997;35:1348-52.

50. Orton SL, Liu H, Dodd RY, Williams AE, ARCNET Epidemiology Group. Prevalence of circulating Treponema pallidum DNA and RNA in blood donors with confirmed-positive syphilis tests. Transfusion. 2002;42:94-9.

51. Sato NS, de Melo CS, Zerbini LC, Silveira EP, Fagundes LJ, Ueda M. Assessment of the rapid test based on an immunochromatography technique for detecting antiTreponema pallidum antibodies. Rev Inst Med Trop Sao Paulo. 2003;45:319-22.

52. Diaz T, Almeida MG, Georg I, Maia SC, De Souza RV, Markowitz LE. Evaluation of determine rapid syphilis TP assay using sera. Clin Diagn Lab Immunol. 2004; 11:98-101.

53. Montoya PJ, Lukehart SA, Brentlinger PE, Blanco AJ, Floriano F, Sairosse J. Comparison of the diagnostic accuracy of a rapid immunochromatographic test and rapid plasma reagin test for antenatal syphilis screening in Mozambique. Bull World Heath Organ. 2006;84:97-104.

54. Zarakolu P, Buchanan I, Tam M, Smith K, Hook EW 3rd. Preliminary evaluation of an immunochromatographic strip test for specific Treponema pallidum antibodies. J Clin Microbiol. 2002;40:3064-5.

55. Siedner M, Zapitz V, Ishida M, De La Roca R, Klausner JD. Performance of rapid syphilis test in venous and fingerstick whole blood specimens. Sex Transm Dis. 2004;31:557-60.

56. Centers for Disease Control and prevention (CDC).
Sexually transmitted disease. Treatment guideline 2002. MMWR Morb Mortal Wkly Rep. 2002;51 RR-6.

57. Maya TC, Maceira JP. Sífilis. In: Dermatopatologia bases para o diagnóstico morfológico. São Paulo:Roca; 2001 p.101-2.

58. Sanchez PJ, Wendel GD. Syphilis and pregnancy. Clin Perinatol. 1997;24:71-90.

59. Mascola L, Pelosi R, Alexander CE. Inadequate treatment of syphilis in pregnancy. Am J Obstet Gynecol. 1984; 150:945-7.

60. Mitchell SJ, Engelman J, Kent CK, Lukehart SA, Godornes C, Klausner JD. Azithromycin-resistant syphilis infection: San Francisco, California, 2000-2004. Clin Infect Dis. 2006; 42:337-45.

61. Lukehart SA, Godornes C, Molini BJ, Sonnett P, Hopkins S, Mulcahy F. Macrolide resistance in Treponema pallidum in the United States and Ireland. N Engl J Med. 2004;351:154-1588.

62. Riedner G, Rusizoka M, Todd J, Maboko L, Hoelscher M, Mmbando D. Single-dose azithromycin versus penicillin $G$ benzathine for the treatment of early syphilis. N Engl J Med. 2005;353:1236-44.

63. Vaughan C, Cronin CC, Walsh EK, Whelton M. The Jarisch-Herxheimer reaction in leptospirosis. Postgrad Med J. 1994;70:118-21.

64. Maloy AL, Black RD, Segurola RJ. Lyme disease complicated by Jarisch-Herxheimer reaction. J Emerg Med. 1998;16:437-8.

65. Webster G, Schiffman JD, Dosanjh AS, Amieva MR, Gans HA, Sectish TC. Jarisch-Herxheimer reaction associated with ciprofloxacina administration for tickborne relapsing fever. Pediatr Infect Dis J. 2002;21:571-3.

66. Guggenhein JN, Haverkamp AD. Tick-borne relapsing fever during pregnancy: a case report. J Reprod Med. 2005;50:727-9.

67. Klein VR, Cox SM, Mitchell MD, Wendel GD Jr. The Jarisch-Herxheimer reaction complicating syphilotherapy in pregnancy. Obstet Gynecol. 1990;75(3 pt1):375-80.

68. Rompalo AM. Can syphilis be erradicated from the world? Curr Opin Infect Dis. 2001;14: 41-4.
MAILING ADDRESS:
João Carlos Regazzi Avelleira
Rua Diamantina 20. Jardim Botânico
22461-050 Rio de Janeiro RJ
Tel.: +552122943387
E-mail: avelleira@unikey.com.br 
1. T. pallidum divides approximately every:
a) 12 hours
b) 30 hours
c) 7 days
d) 14 days

2. The only characteristic that is not found in hard chancre is:
a) clear basis
b) regional lymph node reaction
c) single lesion
d) pain

3. Which secondary syphilis lesions are important in terms of contagion?
a) tuberous circinated lesions
b) facial lesions of "elegant" syphilis
c) inguinocrural region condylomas
d) palmoplantar lesions

4. Tertiary syphilis lesions may appear after a long latency period. The presumptive diagnosis is suggested by:
a) symmetrical lesions
b) tendency to present vegetative lesions
c) large number of lesions
d) more localized lesions

5. Cardiovascular syphilis affects more often the:
a) endocardium
b) ascending aorta
c) descending aorta
d) myocardium

6. The earliest neurological involvement of syphilis is:
a) tabes dorsalis
b) gommatous neurosyphilis
c) progressive general paralysis
d) meningeal alterations

7. In which stage of pregnancy the embryo becomes infected?
a) any stage
b) first trimester
c) second trimester
d) third trimester

8. In children born with recent congenital syphilis, a clinical characteristic that may help in making diagnosis is:
a) presence of cervical hypochromic lesions
b) presence of chancre and secondary lesions
c) rhinitis with mucous and bloody discharge
d) presence of mixed chancre

9. One characteristic of syphilitic patients who are HIV-infected is:
a) poor response to penicillin
b) development of cardiovascular complications
c) more frequent and early neural involvement
d) absence of inoculation chancre

10. In terms of public health services, the most concerning aspect of the association of syphilis and HIV is:

a) possibility of early neurological involvement

b) need to change the recommended therapeutic regimen

c) greater number of cases of resistant $T$. pallidum

d) genital lesions increase the risk of transmitting the HIV

11. The dark field microscopy is a laboratory tool that should be used:

a) if there are no fluorescent microscopes available

b) in primary syphilis chancre

c) in gommatous lesions of tertiary syphilis

d) to confirm the VDRL result

12. The false-negative results in non-treponemic tests, the so-called prozone effect, are due to:
a) small number of treponemas in this stage
b) low specificity of cardiolipin
c) an excess of antibodies
d) very concentrated serum

13. Today the treponemic tests are used primarily:
a) to confirm the cases of syphilis
b) in diagnosis of neurosyphilis
c) to control cure in cases of syphilis
d) to screen cases of syphilis 
14. The rapid tests may significantly help controlling syphilis. The most promising rapid test seems to be:
a) treponema immobilization test
b) FTA
c) immunochromatographic test
d) Western-blot

15. A pregnant woman was treated with erythromycin $2 \mathrm{~g}$ /day for 15 days. What could we comment about the therapeutic regimen used?

a) incomplete treatment; pregnant women should be treated for 30 days

b) penicillin is the only drug considered effective in pregnant women

c) correct treatment, provided it is a case of primary syphilis

d) it should not have been used for causing many side effects

16. In laboratory tests for neurosyphilis, the most important finding to confirm the diagnosis is:
a) increased cellularity in CSF
b) positive FTA-ABS
c) positive VDRL
d) increased proteins in CSF

17. What is the mechanism of action of penicillin against $T$. pallidum?

a) it inhibits the synthesis of folic acid in the treponema

b) it blocks the synthesis of the treponema cell wall

c) it acts directly on the treponema DNA

d) it acts on the ribosome messenger RNA
18. The treatment regimen recommended by the Brazilian Ministry of Health (PN de DST/Aids) for cases of late latent or unknown syphilis is:

a) ceftriaxione + benzathine penicillin

b) crystalline penicillin 3-4 million every 4 hours

c) benzathine penicillin, three weekly doses of 2,400,000 IU

d) benzathine penicillin, two weekly doses of 2,400,000 IU

19. Benzathine penicillin is the first line drug to treat syphilis because of:

a) its low cost

b) low incidence of side effects

c) its ability to cross the blood brain barrier

d) it maintains therapeutic levels for longer periods

20. The Jarish-Herxheimer reaction was described in other diseases caused by spirochetes, such as leptospirosis and Lyme's disease. Tick the drug that may cause this reaction:
a) garamycin
b) tetracycline
c) chloramphenicol
d) cephalosporin

\section{AWNSERS}

Lymphoproliferative processes of the skin. Part 2 Cutaneous T-cell and NK-cell lymphomas. An Bras Dermatol. 2006;81(1):7-25.

$\begin{array}{ll}1-\mathrm{b} & 11-\mathrm{b} \\ 2-\mathrm{c} & 12-\mathrm{d} \\ 3-\mathrm{d} & 13-\mathrm{b} \\ 4-\mathrm{a} & 14-\mathrm{a} \\ 5-\mathrm{d} & 15-\mathrm{d} \\ 6-\mathrm{c} & 16-\mathrm{c} \\ 7-\mathrm{a} & 17-\mathrm{b} \\ 8-\mathrm{b} & 18-\mathrm{c} \\ 9-\mathrm{c} & 19-\mathrm{d} \\ 10-\mathrm{a} & 20-\mathrm{a}\end{array}$

